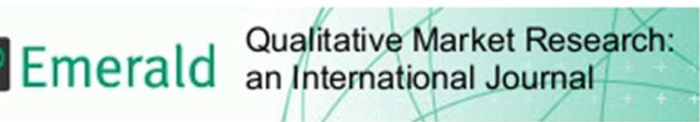

\title{
Corporate social responsibility: engaging the community
}

\begin{tabular}{|r|l|}
\hline Journal: & Qualitative Market Research \\
\hline Manuscript ID & QMR-02-2016-0010 \\
\hline Manuscript Type: & Research Paper \\
\hline Keywords: & $\begin{array}{l}\text { Stakeholder Network, Corporate Social Responsibility, Community, } \\
\text { Philanthropy, Retail Banking }\end{array}$ \\
\hline \multicolumn{2}{|l}{} \\
\hline
\end{tabular}

\section{SCHOLARONE ${ }^{m}$ \\ Manuscripts}




\title{
CORPORATE SOCIAL RESPONSIBILITY: ENGAGING WITH COMMUNITY
}

\begin{abstract}
Purpose: This paper extends corporate social responsibility (CSR) theory by exploring how firms engage with community. The community is frequently cited as a stakeholder of the firm but in spite of its status in networks has not been the focus of research. Drawing on community theory and Carroll's pyramid for the foundation of our study, we undertake an empirical investigation to advance knowledge in CSR engagement with a particular stakeholder group.
\end{abstract}

Design/methodology/approach: To generate in-depth insight, the study adopts a multiple case study approach involving the purposeful selection of three retail banks in Ghana as units of analysis. It draws on multiple data sources to strengthen its findings.

Findings: The study finds that community engagement consists of four spheres of activity: donations, employee voluntarism, projects and partnerships. Philanthropy forms part of largely ad hoc CSR actions by firms. The study also finds that philanthropy is not merely a desired function of the CSR pyramid but an essential one.

Social implications: This research imparts increased understanding of how firms engage with an important but frequently overlooked stakeholder group - community.

Originality/value: This study presents specific theoretical extensions to CSR through its identification of four core activities of community engagement.

Keywords: stakeholder network, corporate social responsibility, community, philanthropy, retail banking.

Paper type: Research paper. 


\section{Introduction}

Stakeholder theory states that a firm can enhance its corporate strategy by recognizing and addressing the complexity of understanding the roles and interactions of firms and stakeholders (Freeman, 1997). Debates on stakeholder theory also draw on the role of social responsibility (for example Greenwood and Van Buren, 2010), in particular where stakeholder network expectations inform a normative framework of social responsibility (Maignan, Ferrell and Ferrell 2005). For this reason, several researchers assess that engagement with stakeholders and different kinds of communities will impact on the firm (Luoma-aho and Paloviita, 2010). The purpose of this paper is to investigate how CSR strategies inform engagement with community. We find that firm CSR strategies consist of five specific spheres of activities as follows: donations, employee voluntarism, projects, partnerships and employee welfare. These activities as yet do not form part of a formalised CSR strategy but are rather more $a d$ hoc, they currently focus on the activity rather than the outcome. Opportunities for optimising the CSR value may not be optimised.

The structure of the paper is as follows: a literature review of corporate social responsibility and community, followed by the research design, findings and a discussion and conclusion section.

\section{Corporate social responsibility}

By identifying and considering a range of stakeholders firms can gain competitive advantage by engaging with customers and other partners and encouraging inter-group engagement (Brodie et al. 2006; Lusch et al. 2007). Each stakeholder in the network confers a particular knowledge set to its relationship with the focal firm and an increase of interest and collaboration (Antonacopoulou and Méric, 2005). Behaviours prompted by this thinking are the generation of products and services that customers are willing to buy, the creation of jobs that employees are willing to fill, the development and maintenance of relationships with 
suppliers that companies are eager to have and, finally, being good citizens in the community (Freeman et al. 2004). The focal firm can boost the goodwill that is associated with commitment to socially responsible behaviours and can consider such behaviours as being part of marketing initiatives (Sen et al. 2006). Such are the positive effects of socially responsible behaviours and the negative effects of CSR violation that most firms not only pay careful attention to CSR issues, but also actively participate in CSR activities (Lai et al. 2010).

Key constructs that emerge from the CSR literature is that it is a social obligation (Clarkson, 1995), it consists of managerial processes (Wood, 1991), it is a stakeholder obligation (Crane and Matten, 2004) and it is ethics-driven (Carroll, 1979). It is also acknowledged that since the business has the resources, the business' management talent, functional expertise and capital should be given a chance to solve social problems (Davis, 1973). Furthermore, the nature of obligations that businesses are expected to attend to is shaped by the economic environment. Much of the research on CSR has focused on its conceptualisation (Carroll, 1979) with contemporary studies on its implementation (Porter and Kramer, 2002; 2006), especially in developing countries. The most commonly described and used concept of CSR in the developed countries is that of Carroll's pyramid (Crane and Matten, 2004). This model proposes relative weightings for four functions of economic, legal, ethical and philanthropic functions, which each need to be fulfilled in order before moving onto the next one in the hierarchy. The economic and legal functions are based on notions of the old social contract and so renders them 'required' expectations of the community, the ethical and philanthropic functions are described as the new social contract; ethical being 'expected' and philanthropic being 'desired' responsibilities (Carroll, 1999). The CSR pyramid by Carroll (1991) has been cited by several authors of CSR (for example, Visser, 2006) and has evolved over two decades (for example Schwartz and Carroll, 2003) thus maintaining its relevance. Our 
concern in this study lies principally with contemporary interpretations and practices of philanthropy, which currently sits at the top of the pyramid as a desired responsibility.

Figure $1 \quad$ CSR pyramid

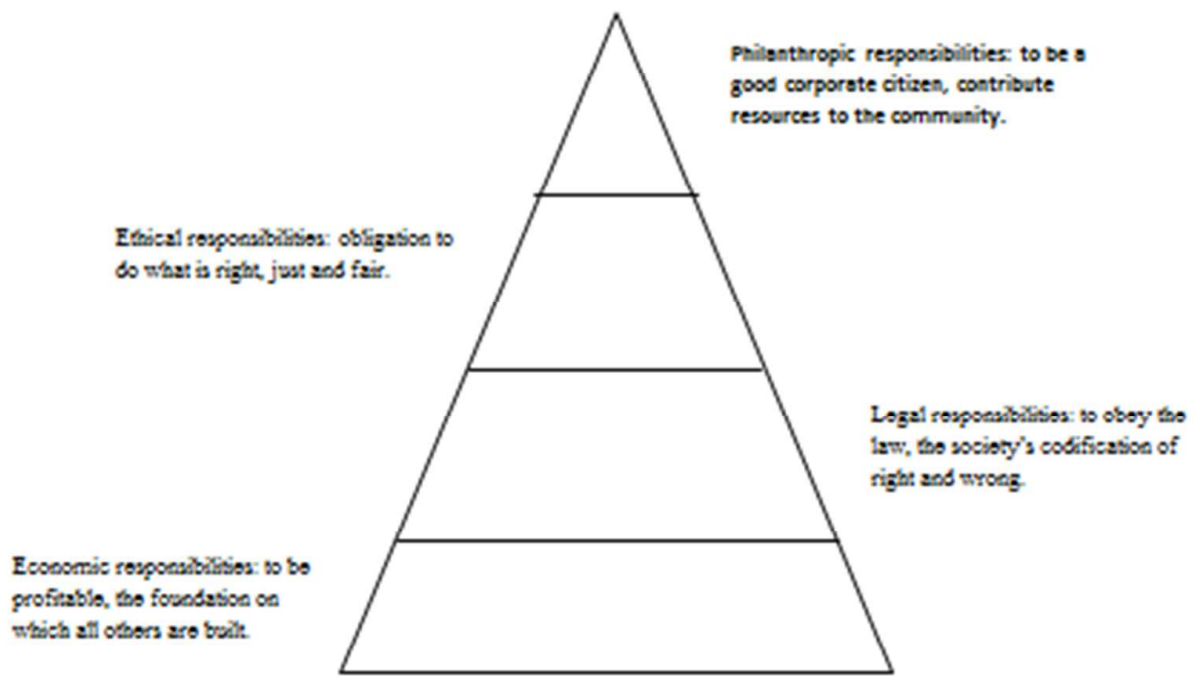

Adapted from Carroll (1991)

According to the model, CSR constitutes four kinds of social responsibility: economic (to make profit), legal (to obey the law), ethical (to be ethical) and philanthropic (to be a good corporate citizen). The model categorises the different responsibilities hierarchically in order of decreasing importance. The most fundamental and highest priority responsibility is economic on which all the other responsibilities are predicated. The expectation at this point is for the organisation to operate a successful business. Legal responsibilities require the organisation to recognise that law is society's codification of right and wrong, hence, to obey the law of the country is essential. Ethical responsibilities are those activities not codified by law and but are expected by a society. The top is philanthropic responsibility which is discretionary in nature. This responsibility requires the organisation to be a good corporate 
citizen by contributing resources to the community and improving quality of life. Overall, the pyramid purports that businesses that deem themselves socially responsible should simultaneously fulfil this set of obligations, taking into consideration their decreasing compliance or obligation.

Corporate philanthropy is a direct contribution of resources by an organisation and its employees to a cause, to improve community well-being or to a charity, most often in the form of cash grants, donation and/or in-kind services (Kotler and Lee, 2005). Although described as being part of the new social contract in the pyramid, philanthropy is the most traditional of all corporate social initiatives and has primarily been a major source of support for communities in health, education, human service agencies, the arts and, in some cases, the environment. According to Kotler and Lee (2005), terminology closely linked to philanthropy includes community giving, community relations, corporate citizenship and community affairs. Increasingly, philanthropy is used as a form of promotion, supporting a company's image or brand through cause-related marketing, even though it still characterises merely a fraction of overall corporate charitable expenditures. Philanthropy thus appears to cover almost any class of charitable action that has some definable approach. In the corporate context, it usually means that there is some connection between the charitable contribution, the firm's business and the way a firm is in contact with its various communities (Porter and Kramer, 2002). We reason accordingly that philanthropy is an appropriate construct through which to explore firm engagement with community.

\section{Community}

The classification of community concerns particular features (Putnam, 2000; Harting et al., 2006; Podnar and Jančič, 2006), such as the place of community affiliation; the country where a community develops; the group of people with whom one carries out some activity 
and shares interests with; the virtual community one takes part in, and so on. The meaning of community may differ according to a particular point of view or discipline such as philosophy, psychology, sociology, anthropology, political sciences, or town planning. Nonetheless, for advancing knowledge, it is helpful to define at least the boundaries of community, which has involved factors of interaction, identity and geography (Lee and Newby, 1983). Freeman et al. (2006) refer to communities of place, communities of interest, virtual advocacy groups and communities of practice. Identifying the different categories of community allows companies to highlight behaviour that they could adopt in managing relationships with their strategic stakeholders (Vos and Schoemaker, 2011; Luoma-aho and Vos, 2009; 2010).

The community to which people may belong may be "no longer the community of place, but an interest community within which a freely communicating society need not be spatially concentrated for we are increasingly able to interact with each other wherever we may be located" (Weber, 1963, p. 68). Community based on elements of interaction (face-to-face or electronic) consists of people that develop social relationships, whether they are living in the same place or not (Godwin, 1997). The value of a community is in its social capital. Social capital has a cognitive dimension through which norms and values are developed (Nahapiet and Ghoshal, 1998). Failure by corporate citizens to adhere to the etiquette defined by social norms in building a relationship can damage any prospect of long-term trust (Anderson and Jack, 2002). Cooke (2002, p. 11) supports and defines social capital as "the expression of norms of reciprocity and trust between individuals and organisations that are embedded in a system of cooperation." Social capital can favour community and can be based on such unifying themes as culture, religion, or spatial proximity. Stocks of social capital, such as trust, norms, and networks, tend to be self-reinforcing and cumulative. These virtuous circles 
may result in social equilibria with high levels of co-operation, trust, reciprocity, civic engagement, and collective well-being. Engaging with a community can enlarge stocks of social capital. Firms have to consider the effects of their activities on communities and their resulting stocks of social capital and may seek to contribute to stocks of social capital while exploiting the value of such stocks.

Consequently, for firms to interact actively, and become an essential part of the community, three types of strategies for interaction are identified as appropriate - collaboration, cooperation and containment. Each strategy involves different goals, tools, actions and interactions. The community relations actions - such as donations and contributions; employee volunteerism; community-based programs; relationships with civic, professional and not-for-profit organizations - have an array of elements in common (Altman, 1997) including: moral and ethical obligations of the firm; provide economic benefits; integration, common goals between corporation and its communities; responsibility to stakeholders; include proactive action; partnerships across sector lines; active leadership.

This discussion suggests that community is a significant stakeholder in the network but as yet there is limited understanding of how firms engage with this particular group or groups. We have proposed Carroll's pyramid as having the capability in providing the theoretical foundation for exploring this engagement. In the context of this study, we focus on engagement with community of place, bound by geographic proximity, common interest, elements of interaction and practice. We now move on to describe the empirical part of the study. 


\section{Research design}

To build on existing work on CSR and engagement with a particular stakeholder group, we conduct our study in a developing country - Ghana. Work by Visser (2006) has already theorised that Carroll's pyramid has some application in Africa but we reason that the vastness and divergence of the continent merits further empirical work. We chose the retail banking sector where there have been significant changes in the past couple of decades within the country. Globally, retail banking is a sector where CSR activity may contribute to building trust post financial crisis (Farquhar and Robson, 2014), spurring further interest in CSR and its practices (McDonald, 2014). To generate the in-depth and within context knowledge of CSR and community engagement, we chose a case study research strategy (Eisenhardt, 1989).

Using purposeful sampling (Patton, 2002), we selected three banks (UT, Fidelity and Access) for our study, following guidance that multiple cases allow for more robust findings (Eisenhardt and Graebner, 2007). Case study research promotes an in-depth focus on phenomenon in its naturalistic setting as an object of interest in its own right (Yin, 2009) and here each unit of investigation presented a real-life, contemporary setting of CSR practices. Multiple sources of data were generated during the period of 2008 to 2013, comprising semistructured interviews, archival data, media and documents, which we developed into a research database (Yin, 2009).

For the primary data collection, we developed an interview guide focusing on questions of how CSR practices were implemented, which particular were promoted and who was engaged in these practices. In each case, we interviewed three senior managers. These managers had been invited to participate because they had direct responsibilities and 
oversight of strategic decision-making and CSR practice in their companies. They were the CEO/Director, Head of Corporate Affairs/Corporate Communications, and Brand Manager/Public Relations \& Media Manager. Although the job roles are similar in terms of the responsibilities of individuals, the job titles differ from case to case. Primary data collection therefore consisted of nine interviews, which were recorded with the informants' consent. Interview length varied between 45 minutes and just under two hours. The primary data were supplemented with memos and further notes to capture immediate thoughts and impressions (Charmaz, 2006).

In accordance with Miles and Huberman (1994), analysis of the data began with writing up these field notes and transcripts into summaries. These summaries informed interview and document coding. Content was coded following as much as possible informants' own language and terms. We then extended these codes across the database of text, that is, documents and archives. We analysed first the data within each case and then as our confidence in the interpretation of the data grew we moved onto consider the codes across the cases (Denzin, 1978). Constant and repeated comparison of data across informants revealed major emerging concepts of the phenomenon (Patton, 2002). When an in vivo code was not directly available or would violate confidentiality agreements then short phrases expressed in first-order terms were used. As the transcripts were read and reread, new codes were created and existing codes were adjusted. Constant iteration took place between data sets, emerging theory, and relevant literature to identify the practices of CSR with relation to community.

First order practices were extracted which unlocked meaning in the data but needed to uncover the deeper patterns in the data. A more structured second-order analysis provided a greater degree of abstraction (Miles and Huberman, 1994) enfolding the literature in 
supporting the emerging categories (Eisenhardt, 1989). A third analytical stage consolidated the themes into categories of CSR activities or practices that encompassed the data. These categories are as follows: donations, employee voluntarism, projects and partnerships. We present and discuss our findings in the following section.

\section{Findings and discussion}

In this section we organise our discussion around the four categories which emerged from the analysis. We have condensed the evidence supporting the final category development in Table 1.

\section{Donations}

Giving was primarily in the form of cash donations, events for fund-raising and giving of resources such as equipment to NGOs, educational institutions and hospitals. According to Carroll et al. (1999), philanthropic responsibilities of an organisation are a "desired" social contract to the community and therefore remain a totally voluntary part of CSR. However, these banks seem to apportion a high level of importance in a manner that portrays the community depends on their donations and contributions. From an organisation's perspective, one bank states that philanthropy is one of the reasons for its current successful business operations; hence, this activity remains essential collateral for community relations. When questioned about the motivation behind these donations and contributions, Fidelity bank admitted that the public relations benefit derived were worth the effort and financial sacrifice to create value in the community, thus, enhancing the organisation's reputation and the longrun financial performance of the firm. Philanthropy in this study seems to be used strategically by the banks for the purpose of building a good image and reputation - a finding in accordance with Lantos (2001). 
Table 1: Evidence for dimensions

\begin{tabular}{|c|c|c|c|}
\hline $\begin{array}{l}\text { Third order } \\
\text { categories }\end{array}$ & UT Bank & Fidelity Bank & Access Bank \\
\hline Donations & $\begin{array}{l}\text { Philanthropy is one aspect of CSR we cannot do } \\
\text { away with. } \\
\text { It's so important ..., but those we give donations } \\
\text { to on an annual basis look forward to it. } \\
\text { And we work on Social Upliftment - which } \\
\text { involves donations to our Orphanages." }\end{array}$ & $\begin{array}{l}\text { In the past, we have provided a GHS50,000 } \\
\text { water network support to the military academy } \\
\text { at the Teshie camp. } \\
\text { In the past } 3 \text { years we have provided financial } \\
\text { aid to students of University of Ghana, and we } \\
\text { have signed a contract up to } 2015 \text { to give them } \\
\text { GHS72,000 per year." } \\
\text { What we also did was to provide financial } \\
\text { support to the } 37 \text { Military Hospital to purchase } \\
\text { and install an MRI scanner... at the same time } \\
\text { gave them Cedis } 20,000 \text { to refurbish the building } \\
\text { in which they installed the machine. }\end{array}$ & $\begin{array}{l}\text { The bank was the first institution to donate } \\
\text { money to the Global Fund - I think we gave } \\
\text { them } \$ 1 \text { million. So for example if we were } \\
\text { supporting a school needing a computer lab, we } \\
\text { would provide funding to cover the cost of build } \\
\text { or refurbishment, and purchase of computers. }\end{array}$ \\
\hline $\begin{array}{l}\text { Employee } \\
\text { volunteerism }\end{array}$ & $\begin{array}{l}\text { We engage staff on the road show for our } \\
\text { Financial Literacy Programme. }\end{array}$ & $\begin{array}{l}\text { For example, if the issue requires community } \\
\text { cleaning, the local branch is better placed to take } \\
\text { this up and make an impact, build intimacy, } \\
\text { trust, positive perception and a shared } \\
\text { responsibility with the branch manager, staff } \\
\text { and community, no matter how small the giving } \\
\text { is. } \\
\text { I'm hoping we can set up a strong employee } \\
\text { volunteering programme, where they will be } \\
\text { allowed to do what they want to do. } \\
\text { The volunteering will fit in the financial literacy } \\
\text { programme, because that is key. }\end{array}$ & $\begin{array}{l}\text { We have branch clusters, so for instance, we } \\
\text { have a branch in Osu, Oxford, another in Osu, } \\
\text { Watson, etc they form one cluster and they take } \\
\text { care of EVP specific to the area's needs. } \\
\text { In Accra only, we have } 14 \text { different EVP groups } \\
\text { now. }\end{array}$ \\
\hline Projects & $\begin{array}{l}\text { We have a major CSR function that takes place } \\
\text { every year between April - May where the team } \\
\text { travels around the country to serve our } \\
\text { customers in the communities - it's called the } \\
\text { Financial Interest Programme. } \\
\text { UT's current strategy is to get } 300,000 \\
\text { customers to bank with us by the end of } 2013 \text {. } \\
\text { So every community activity and every plan is } \\
\text { geared towards that. In going into the market, } \\
\text { we not just training them to keep their books but }\end{array}$ & $\begin{array}{l}\text { My general direction is to focus our efforts of } \\
\text { community programmes around financial } \\
\text { services, which is our core business. } \\
\text { However, we recognise that we are in a very } \\
\text { deprived country... people get their cash and } \\
\text { have money, where do they spend their money } \\
\text { most - it's in education, in health and in } \\
\text { housing. Those are the areas with the big need. } \\
\text { So in terms of the social agenda, that's where I } \\
\text { will focus things on. }\end{array}$ & $\begin{array}{l}\text { We want to be the most respected bank in } \\
\text { Ghana and Africa. This we believe will be } \\
\text { majorly driven by our commitment to } \\
\text { community investment and CSR" } \\
\text { Community investment programmes look at } 5 \\
\text { thematic areas of health, education, } \\
\text { environment, culture and sports. } \\
\text { "Sometimes, even our business ideas our driven } \\
\text { by our community projects. }\end{array}$ \\
\hline
\end{tabular}




\begin{tabular}{|c|c|c|c|}
\hline & $\begin{array}{l}\text { also encourage them to save with us as well. } \\
\text { It's also important our CSR is in tandem with } \\
\text { our core business practice - this becomes easier, } \\
\text { we have the skills to deliver it and it helps our } \\
\text { business too. Hence, our Financial Literacy } \\
\text { Programme. We have another programme } \\
\text { coming up in the Ashanti region in Kumasi } \\
\text { called "Wu sika tisen"(How is your money?). }\end{array}$ & $\begin{array}{l}\text { Out of a population } 24 \text { million, there are } 22 \\
\text { million SIMs in a holistic and embracing way; } \\
\text { this is CSR because the majority of these people } \\
\text { are unbanked. And quite a lot of the unbanked } \\
\text { live in conditions of deprivation, a lot of which } \\
\text { is increasingly being resolved at the macro level } \\
\text { by the government, so what's left for us to do is } \\
\text { to take financial inclusion, knowledge transfer } \\
\text { and skills enhancement and capacity building. }\end{array}$ & $\begin{array}{l}2 \text { years ago, we assembled } 120 \text { SMEs and } \\
\text { delivered a workshop in partnership with } \\
\text { Friends of Africa - a one day training on how to } \\
\text { develop workplace policies with facilitators } \\
\text { from across Africa and Asia. }\end{array}$ \\
\hline Partnerships & $\begin{array}{l}\text { We also bought a Mobile Screening Unit which } \\
\text { we use in the communities in collaboration with } \\
\text { Cancer Society of Ghana with GIZ formally } \\
\text { GTZ and its based on a } 3 \text { year partnership we } \\
\text { have with them. } \\
\text { Based on these partnerships, we are able to align } \\
\text { our CSR to fall in line with the Millennium } \\
\text { Development Goals - } 4 \text { of them - maternal } \\
\text { health, child mortality, poverty alleviation and } \\
\text { malaria. } \\
\text { We have an entrepreneurial programme with } \\
\text { business starters whom we also give some } \\
\text { business grant to do their business and monitor } \\
\text { how well they do. }\end{array}$ & $\begin{array}{l}\text { We are pioneering agency banking in Ghana, } \\
\text { which means that shops, pharmacies, retailers, } \\
\text { etc can all become banking agents. } \\
\text { We are working with Care International to use } \\
\text { our agency banking model to reach savings } \\
\text { groups, so we can partner with these guys. }\end{array}$ & $\begin{array}{l}\text { We invest in building skills so we support } \\
\text { Students Unions in universities to support them } \\
\text { in building relationships with businesses to } \\
\text { provide them with opportunities in internships } \\
\text { and placements. } \\
\text { That football there is from an "Alive \& } \\
\text { Kicking" campaign in partnership with a British } \\
\text { NGO, recently registered in Ghana helping } \\
\text { disability people to get jobs so they train them to } \\
\text { make handmade footballs. So typically, our } \\
\text { interests are to support their cause which is } \\
\text { giving skills and jobs to people with disabilities } \\
\text { and that will benefit the community. }\end{array}$ \\
\hline
\end{tabular}


Giving which supports education institutions or provides financial aid to university students also strengthens the quality of human resources or physical infrastructure upon which the business success depends in the long run.

Both the community and the bank thus prosper. In terms of the approach, one informant stated that this activity was done on an ad hoc basis. Elsewhere the findings indicate that the cases supported a strategic approach as being more sustainable for the businesses. Attempts to make donations consistent had been going on for three years in one of the cases and in another a five year contract had just been signed. These efforts indicate long-term relationships although they are not repeated in all the cases. There is however the implication of a co-operation approach to CSR as they continue to develop mutual understanding of the needs of the community and their respective constructive feedback (Freeman et al. 2006).

\section{Employee volunteerism}

Employee volunteerism programmes (EVP) across the three cases were variable. One case was dependent on this dimension for its community engagement. The second case seemed to adopt a rather intermittent approach and in the third there was no evidence of this activity. It was acknowledged that EVP was important in reaching the community. The bank most active in EVP was adamant on keeping EVP at a local community level, thus ensuring the branches met the real needs of the specific community. In order to understand what the local community needs are, requires an ongoing dialogue from the bank which is consistent with one of the key actions mentioned by Freeman et al. (2006). However, there was little evidence of formal dialogue between the banks and the communities but rather mostly reactive responses to requests from individuals and institutions to support their causes. In addition, the narrow geographical proximity implies the recognition of community needs in one local community anticipates similar needs elsewhere (Leisinger, 2007). 
Although employees play this pivotal role in philanthropic community engagement, there was limited evidence of how the banks supported employees. This is in contrast to developed economies such as the US and Europe, where the role and rights of employees are fundamental and have been long-standing items on CSR agendas with organisations (Matten and Moon, 2008). The idea of a basic good salary and some benefits such as healthcare seemed sufficient. According to Dartey-Baah and Amponsah-Tawiah (2011), there are many CSR issues on employee welfare that firms in Ghana should be concerned with - amongst others, rising unemployment, employee protection and wages, and discrimination against women in the workplace. Indeed, one informant indicated that human resources was solely responsible for welfare of employees in that particular bank.

\section{Projects}

Projects were very varied. One consisted of training centred on the development of financial skills (The Financial Literacy Programme). Representatives of the bank visit communities around the country to train customers and traders in book-keeping and saving. The same bank also runs an entrepreneurial programme for start-ups which provide business grants on due diligence and mentoring to ensure the businesses are sustainable. This is in line with the bank's current strategy to obtain 300,000 customers by the end of 2013. Porter and Kramer (2002) recommend that corporations analyse their prospects for social responsibility using the same framework that guides their core business choices, in so doing, they would discover that CCR can be a source of opportunity, innovation and competitive advantage. Therefore, social investments through community-based programmes are potentially cost-effective ways to build the business and improve competitiveness. A collaborative approach between the bank and community supports the shared objectives and identity, including a longer term commitment to build on shared visions between the bank and the community to promote trust and add to the value of social capital within that community. 
Apparent recognition to move towards sustainable practices that utilise the skills and expertise within the business, hence, the Financial Literacy Programme, the SME training workshops and the agency banking model to improve financial inclusion presents challenging opportunity to formalise policies and structures for CSR practices in the banking sector.

\section{Partnerships}

These projects are implemented in partnership with other organisations, such as NGOs and charities. According to the evidence in the study, these partnerships are forged to work on maternal health, child mortality, poverty alleviation and malaria. These areas do not necessarily have any synergy with the core business of the banks so the value of these actions on the overall strategy of the cases may need further action. These tensions are ongoing and lead to identifying the wants and needs of community. This dimension reveals efforts to understand the distinctive features of their stakeholders by drawing on the strengths of specialist organisations to engage with another stakeholder, that is, community. Firms may lack the specialist resources to involve themselves effectively in public welfare issues (Shaw and Barry, 1992), hence rely on partnerships with non-profit organisations to do so.

Consequently, strategies for engagement with communities via their relationships with other organizations/stakeholders are identified as co-operation and sometimes collaboration strategies (Freeman et al. 2006). These interactions allow the bank and partner organisations to identify and organise useful and functional activities and programmes which coordinate and integrate with each other to create stocks of social capital with the community, as well as provide economic benefits for the bank.

There was also evidence of collaboration with global for profit firms principally to create business opportunities with technology. This particular activity brought together both philanthropy and corporate strategy as through an investment in technology with the 
aspiration of capturing larger market share. Through this investment, this increase in market share would ultimately help in putting in place the processes and services to reach the unbanked. According to PricewaterhouseCoopers Survey Report 2010, transformation of technology and information systems is the backbone for improving service delivery and sustaining product development. Pioneering organisations integrate social initiatives into their core activities by actively channelling their research and development capabilities towards socially innovative products and services. This technological advancement in the bank is linked directly to developing their CSR strategy on financial inclusion.

\section{Conclusions}

The purpose of this study was to explore firm CSR practices or activities with a particular stakeholder group, that is, community. We identified four categories of community engagement undertaken by the cases in the study as follows: donations, employee voluntarism, projects and partnerships. These categories took in key operational sectors such as health, education, women and children, arts, sports and housing or infrastructure.

Although employee volunteerism has unique characteristics and could potentially be distinguished as a separate initiative, some models and definitions (Porter and Kramer, 2002) include it as a form of corporate philanthropy (see also Schwartz and Carroll, 2003). CSR directly impacts the very people who invest in the company, therefore creating a cycle of benefit for both the organisation and the community. Strategic corporate social investment's legitimate focus allows for a meaningful benefit for society, which is also valuable to the business, (Porter and Kramer, 2002). It is more beneficial to a firm if their social and economic goals are not inherently conflicting, but rather integrally connected.

It is evident in the data that the banks seek to behave responsibly towards community. In the definitions of their understanding of CSR, all the managers described it as activities targeted 
to the community for a positive impact in various ways such as reducing poverty, financial support, knowledge transfer and skills enhancement in the area of capacity building. The community sectors in which the banks operate are similar and overlapping - education, health, sports, culture and arts, and social 'uplift'. The move of philanthropy towards sustainable CSR delivery to the community is described variously by informants as "social investment", "community investment" and "impacting the community in such a way that the business grows". The latter specifically refers to the banks community relations strategy and activities geared towards meeting their business development goals. This is supported by Porter and Kramer (2002) who pointed out that it is more beneficial to a firm when their social investments provide economic returns. However, there is the challenge of how closely linked these social interventions are linked to the business' core operations. In any case, this changes the notion of social contract for philanthropic actions from 'desired' to 'expected' responsibilities.

There is the lack of formal dialogue between these banks and community as decisions are primarily made at executive management level at managers' discretion and/or by use of "relevance" criteria identified by the bank in the priority sectors, where the focus is on one sector for example health for the whole year, which is thought to be more impactful in the community. Where there is reliance of another bank on a local partner organisation, the decision to fund or support a particular community project may be driven by the NGOs agenda. Whether community engagement is achieved delivered through donations, employee volunteerism (EVPs), training or partnerships, the study finds that community engagement benefits include community perception of the banks. These benefits include good corporate reputation, trust building trust and increased customer loyalty. 
This study makes several contributions. Theoretically the study extends CSR theory by illuminating how a firm engages with a particular stakeholder in this case, community through four spheres of activity. These four spheres may form the basis of strategic engagement. The study also finds that community is potentially an important stakeholder group in the firm network and that engagement is enhanced through partnerships with other stakeholders and organisations, who may not yet be within the network. Thus engaging with community has the potential to extend the network.

The study also finds that in some instances philanthropy may be strategic but remains largely an ad hoc component of CSR. The findings indicate that the cases engage with community by providing significant resources which promote social welfare and community goodwill but at the same time fulfil very real needs so that retail banks have no option but to provide it. This obligation on retail banks changes philanthropy from a desired response of the pyramid to an expected responsibility or even an essential category. This removes philanthropy from the discretionary level of the pyramid, redefining it as essential and thus at the same level as economic and legal in the pyramid (see Figure 1).

Whilst the engagement and CSR initiatives outlined above are of benefit to the community and the firm, they are planned on an ad hic basis. Further benefit could be gained by incorporating such initiatives into a strategic plan and thus aligning them with other community and stakeholder activities.

This study on community engagement and CSR serves as a basis for recommendations for further research. Further work in CSR could focus on the development of community engagement and community relations strategies which fit into the overall corporate strategy. 
Secondly, the findings depict community actions rather than outcomes. The outcomes would provide evidence to continued firm engagement with community and assist in building positive perceptions, corporate reputation, trust and customer loyalty.

\section{References}

Altman, B. (1997), Corporation Community Relations in the 1990's: A study in Transformation, Unpublished Dissertation, Boston, Boston University School of Management.

Amponsah-Tawiah, K. and Dartey-Baah, K. (2011), “Corporate social responsibility in Ghana”, International Journal of Business and Social Science, Vol. 2 No. 17, pp. 107-112.

Anderson, A. and Jack, S. (2002), "The effects of embeddedness on the entrepreneurial process", Journal of Business Venturing, Vol. 17 No. 5, pp. 467-487.

Antanacopoulou, E. and Méric, J. (2005), “A critique of stake-holder theory: management science or a sophisticated ideology of control?" Corporate Governance: The International Journal Of Business In Society, Vol. 5, No. 2, pp. 22-33

Brodie, R., Glynn, G. and Little, V. (2006), “The service brand and the service-dominant logic: missing fundamental premise or the need for stronger theory?" Marketing Theory, Vol. 6, No. 3, pp. 363-379.

Carroll, A. (1979), “A three-dimensional conceptual model of corporate performance”, Academy of Management Review, Vol. 4, No. 4, pp. 497-505.

Carroll, A. (1991), "The pyramid of corporate social responsibility: toward the moral management of organizational stakeholders”, Business Horizons, Vol. 34 No. 4, pp. 39-48.

Carroll, A. (1999), “Corporate social responsibility”, Business \& Society, Vol. 38 No. 3, pp. $268-295$.

Charmaz, K. (2006), Constructing Grounded Theory, Sage Publications, London. 
Cooke, P. (2002), The Learning Economies: Clusters, learning and cooperative advantage, London: Routledge.

Crane, A. and Matten, D. (2004), Business Ethics: A European perspective: managing corporate citizenship and sustainability in the age of globalisation, Oxford, Oxford University Press.

Davis, K. (1973), “The case for and against business assumption of social responsibilities”, Academy of Management Journal, Vol. 16 No. 2, pp. 312-323.

Dean, D. (2004), "Political Research and Practitioners Approaches: a review of the research methods used in voting behaviour research", Journal of Public Affairs, Vol. 4 No. 2, pp. 145-154.

Denzin, N. (1978), The Research Act, Chicago, Aldine.

Eisenhardt, K. (1989), “Building Theories from Case Study Research”, Academy of Management Review, Vol. 14, No. 4, pp. 532-550.

Eisenhardt, K. and Graebner, M. (2007), “Theory building from cases: opportunities and challenges", Academy of Management Journal, Vol. 50 No. 1, pp. 25-32.

Farquhar, J. and Robson, J. (2014), “A Brave New World: Branding financial services”, in (eds). T. Harrison and H. Estelami, Companion to Financial Services Marketing, Routledge, London, 204-218.

Freeman, R. (1997), "Stakeholder theory", in (eds) P. Werhane and R. Freeman, The Blackwell Encyclopaedic Dictionary of Business Ethics, Blackwell, Oxford/Malden, MA. pp. 602-606.

Freeman, R.E. (1984), Strategic Management: A Stakeholder Approach, Boston: Pitman Publishing.

Freeman, R., Wicks, A. and Parmar, B. (2004), "Stakeholder Theory and the Corporate Objective Revisited", Organization Science, Vo. 15, No. 3, pp. 364-369 
Freeman, R.E., Dunham, L. and Liedtka, J. (2006), “Enhancing Stakeholder Practice: A Particularized Exploration of Community", Business Ethics Quarterly, Vol. 16, Issue 1, pp. $23-42$.

Godwin, R.K. (1997), “Money, Technology and Political Interests: the Direct Marketing of Politics", in M. Petracca (ed.), The Politics of Interests: Interest Group Transformed, Colorado: Westview Press Boulder.

Greenwood, M. and Van Buren, H. (2010), Trust and Stakeholder Theory: Trustworthiness in the Organisation-Stakeholder Relationship, Journal of Business Ethics, 95(3) 425-438.

Harting, T.R., Harmeling, S.S. and Venkataraman, S. (2006), “Innovative Stakeholder Relations: When “Ethics Pays” (And When It Doesn't)”, Business Ethics Quarterly, Vol. 16 No. 1, pp. 43-68.

Kotler, P. and Lee, N. (2005), Corporate Social Responsibility: Doing the Most Good for Your Company and Your Cause, Hoboken, John Wiley \& Sons.

Lai, C-S., Chiu, C-J., Yang, C-F. and Pai, D-C. (2010), 'The effects of corporate social responsibility on brand performance: the mediating effect of industrial brand equity and corporate reputation', Journal of Business Ethics, Vol. 95, No. 3, pp. 457-469.

Lantos, G P. (2001), “The boundaries of strategic corporate social responsibility, Journal Of Consumer Marketing”, Vol. 18, No. 7, pp. 595-632.

Lee, D. and Newby, H. (1983), The Problem of Sociology: an Introduction to the Discipline, London: Hutchinson.

Leisinger, K. (2007), “Corporate Philanthropy: The "Top of the Pyramid”, Business and Society Review, Vol. 112, No. 3, pp. 315-42.

Luoma-aho, V. and Paloviita, A. (2010), “Actor-networking stakeholder theory for today's corporate communications", Corporate Communication: An International Journal, Vol. 15 No. 1, pp. 49-67. 
Luoma-aho, V. and Vos, M. (2009), "Monitoring the Complexities: Nuclear power and public opinion", Public Relations Review, Vol. 35, pp. 120-122.

Luoma-aho, V., and Vos, M. (2010), "Towards a more dynamic stakeholder model: acknowledging multiple issue arenas", Corporate Communications: An International Journal, Vol. 15, No. 3, pp. 315-331.

Lusch, R., Vargo, S. and O’Brien, M. (2007), “Competing through service: Insights from service-dominant logic", Journal of Retailing, Vol. 83, No. 1, pp. 5-18.

McDonald, L. (2014), “Corporate Social Responsibility in banking: what we know, what we don't know and what we should know", in (eds). T. Harrison and H. Estelami, Companion to Financial Services Marketing, London, Routledge, pp. 485-505.

Maignan, I., Ferrell, O. and Ferrell, L. (2005), “A stakeholder model for implementing corporate social responsibility in marketing”, European Journal of Marketing, Vol. 39, No. 9/10, pp. 956-977.

Matten, D. and Moon J. (2008) "Implicit" and "explicit" CSR: A conceptual framework for a comparative understanding of corporate social responsibility", Academy Of Management Review, Vol. 33, No. 2, pp 404-424.

Miles, M., and Huberman, A (1994), Qualitative data analysis: An expanded sourcebook, Thousand Oaks, Sage Publications.

Nahapiet, J. and Ghoshal, S. (1998), "Social Capital, Intellectual Capital, and the Organizational Advantage", Academy of Management Review, Vol. 23 No. 2, pp. 242-66.

Patton, M. (2002), Qualitative evaluation and research methods (3rd ed), Thousand Oaks, Sage Publications.

Podnar, K. and Jančič, Z. (2006), “Towards a categorization of stakeholder groups: an empirical verification of a three-level model”, Journal of Marketing Communications, Vol. 12, No. 4, pp. 297-308. 
Polonsky, M., Schuppisser, S. and Beldona, S. (2002), “A Stakeholder Perspective for Analyzing Marketing Relationships", Journal of Market-Focused Management, Vol. 5, pp. 109-126.

Porter, M. and Kramer, M. (2002), “The competitive advantage of corporate philanthropy”, Harvard Business Review, Vol. 80, No. 12, pp. 56-68.

Porter, M. and Kramer, M. (2006), "Strategy and society”, Harvard Business Review, Vol. 84, No. 12, pp. 78-92.

PricewaterhouseCooper (2010), “CSR Trends”, pwc.com/ca/en/sustainability/publications/csr-trends-2010-09.pdf, downloaded, $30 / 03 / 2012$.

Putnam, R. (1993), Making Democracy Work: Civic Traditions in Modern Italy, New Jersey Princeton: Princeton University Press.

Putnam, R. (2000), Bowling Alone: The Collapse and Revival of American Community, New York: Simon and Schuster.

Schlegelmilch, B. and Pollach, I. (2005), “The perils and opportunities of communicating corporate ethics", Journal of Marketing Management, Vol. 21, No. 3/4, pp. 267-290.

Schultz, D.E. and Kitchen, P.J. (2004), "Managing the Changes in Corporate Branding and Communication: Closing and Re-opening the Corporate Umbrella", Corporate Reputation Review, Vol. 8 No. 4, pp. 347-366.

Schwartz, M and Carroll, A. (2003), "Corporate Social Responsibility: A Three-Domain Approach", Business Ethics Quarterly, Vol. 13, No. 4, pp. 503-530.

Sen, S., Bhattacharya, C. and Korschun, D. (2006), "The role of corporate social responsibility in strengthening multiple stakeholder relationships: A field experiment”, Journal of the Academy of Marketing Science, Vol. 34, No. 2, pp. 158-166.

Shaw, W. and Barry, V. (2004), Moral issues in business, Belmont CA, Cengage. 
Visser, W. (2006), “Revisiting Carroll’s CSR Pyramid: An African Perspective”, downloaded from www.waynevisser.com/wpcontent/uploads/2012/04/chapter_wvisser_africa_csr_pyramid.pdf, 23/05/2014.

Vos, M. and Schoemaker, H. (2011), Integrated communication: concern, internal and marketing communication, (4th edition), The Hague, Eleven Publishing.

Waldman, D., de Luque, M., Washburn, N. and House, R. (2006), "Cultural and leadership predictors of corporate social responsibility values of top management: a GLOBE study of 15 countries", Journal of International Business Studies, Vol. 37, No. 6, pp. 823837.

Weber, M. (1963), “Order in diversity: Community without propinquity”, in Wingo, L. (ed.) Cities and Space, Baltimore, John Hopkins Press.

Wood, D. (1991), “Corporate Social Performance Revisited”, Academy of Management Review, Vol. 16, pp. 691-718.

Yin, R. (2009), Case study research (4th edition), Thousand Oaks, Sage Publications. 